\title{
РЕАЛІЗАЦІЯ КОМПЕТЕНТНІСНОГО ПІДХОДУ В УМОВАХ СУЧАСНОЇ УКРАЇНСЬКОЇ СЕРЕДНЬОЇ ШКОЛИ ЯК ОСНОВА ФОРМУВАННЯ ОКРЕМИХ КОМПЕТЕНТНОСТЕЙ СТАРШОКЛАСНИКІВ
}

Павленко I. C. Реалізація компетентнісного підходу в умовах сучасної української середньої школи як основа формування окремих компетентностей старшокласників.

У статті висвітлюються основні аспекти реалізації компетентнісного підходу в умовах сучасної української середньої школи як основи формування окремих компетентностей старшокласників. Автор конкретизує змістове наповнення понять «компетенція» та «компетентність», у яких утілюється компетентнісний підхід, спираючись на науковий доробок провідних українських і зарубіжних науковців.

Ключові слова: компетентність, компетентнісний підхід, формування компетентностей, середня школа.

Павленко И. С. Реализация компетентностного подхода в условиях современной украинской средней школы как основа формирования отдельных компетентностей старшеклассников.

В статье освещены основные аспекты реализации компетентносного подхода в условиях современной украинской средней школы как основы формирования отдельных компетентностей старшеклассников. Автор конкретизирует смысловое наполнение понятий «компетенция» и «компетентность», в которых воплощается компетентностный подход, опираясь на научный потенциал ведущих украинских и зарубежных ученых.

Ключевые слова: компетентность, компетентносный подход, формирование компетентностей, средняя школа.

Pavlenko I. S. Implementation of a competence approach in the context of modern Ukrainian secondary school as a basis of development of individual competences of senior pupils.

The main aspects of the competence-based approach realization under conditions of modern Ukrainian secondary school as the basis for the formation of high school students' particular competences are highlighted in the article. The author elaborates on the meaning of the concepts of «competence» and «competency»that embody the competence approach, based on scientific potential of leading Ukrainian and foreign scientists.

Key words: competence, competence-based approach, formation of competences, secondary school.

Нині сугтєвих змін зазнає вектор, що зумовлює траєкторію оцінки суспільних пріоритетів і цінностей: визнається самоцінність особистості, іiі здатності до вільного вибору життєвих і професійних шляхів та способів свого саморозвитку. У сучасному соціокультурному й економічному середовищі відбувається становлення нового соціального ідеалу, формування якого характеризується відмовою від ідеї і практики патерналізму на користь особистої компетентності. Уявлення випускника української школи про своє майбутнє пов'язується з особистою активністю, підприємництвом та індивідуальною творчістю, сприймається й оцінюється крізь спектр понять «кар'єрна успішність», «результативність», «високий рівень індивідуального доходу» тощо. Соціально й економічно неуспішні суб'єкти перестають бути еталоном освітнього ідеалу, 
вектор моральної орієнтації розвивається за лінією збільшення поваги до особистості, яка сама себе сформувала, компетентної людини. Водночас освітній процес в українських середніх загальноосвітніх закладах здійснюється корпусом педагогів, які, значною мірою, реалізують свою професійну діяльність на основі паттернів сприйняття діяльності й поведінки, сформованих ще в радянський період. Вони свідомо чи несвідомо транслюють неактуальні для молодої людини ідеологічні, соціокультурні установки, орієнтуючись на свої уподобання та поведінкові стереотипи. Тому впровадження компетентнісно зорієнтованого навчання $є$ потребою часу, відповіддю на наявність проблемного поля освітніх видозмін, невідворотність яких нині є для всіх очевидною.

Компетентнісний підхід $є$ загальновизнаним підходом до оцінювання процесу та результатів шкільного навчання. Науковці-фундатори компетентнісного підходу (Н. Бібік, І. Зимня, О. Овчарук, В. Сєріков, А. Хуторськой) убачають у ньому синтез діяльнісної та особистої складової: як правило, компетентність стосується особистості учня й виявляється у процесі виконання ним певної діяльності або комплексу дій. Більшість сучасних зарубіжних науковців компетентнісний підхід в освіті пов' язують із формуванням здатності або готовності особистості мобілізувати всі свої ресурси (системно організовані знання й уміння, навички, здібності та психічні якості), які необхідні для виконання певного завдання на високому рівні, а також адекватні конкретній ситуації, тобто відповідно до мети й наявних умов. Австралійський дослідник Т. Гофман стверджує, що компетентнісний підхід можна розглядати у трьох площинах: а) очевидних і фіксованих результатів діяльності; б) певних стандартів виконання діяльності; в) особистісних властивостей, які визначають ефективність однієї або іншої діяльності [7, с. 277]. Спираючись на науковий доробок провідних українських i зарубіжних науковців, конкретизуємо змістове наповнення понять «компетенція» та «компетентність», у яких утілюється компетентнісний підхід.

Виходячи 3 цього мета статті полягає у здійсненні грунтовного психологопедагогічного аналізу сучасного розуміння процесів реалізації компетентнісного підходу в умовах сучасної української середньої школи як основи формування окремих компетентностей старшокласників.

Міжнародна комісія Ради Європи розглядає поняття компетентності як загальні або ключові вміння, базові вміння, фундаментальні шляхи навчання, ключові кваліфікації, кроснавчальні вміння або навички, ключові уявлення, опори або опорні знання. Компетентності, на думку експертів РС, передбачають: спроможність особистості сприймати та відповідати на індивідуальні та соціальні потреби; комплекс ставлень, цінностей, знань і навичок [5 с. 19].

Таке визначення поняття компетентностей, зазначають вітчизняні науковці, певною мірою збігається 3 положеннями, що висловлюють українські педагоги, однак представники європейських педагогічних кіл насамперед виходять 3 особистісних i соціальних потреб, задоволенню яких мають сприяти компетентності [5, с. 19].

I. Зимня, цитуючи документ, відомий широкому освітянському загалу під назвою «Стратегії модернізації змісту загальної освіти», указує, що поняття «компетентності» ширше від знань, або вмінь чи навичок, воно охоплює ці поняття (хоча, звичайно, йдеться про елементарну адитивну сукупність знання-уміння-навички; це поняття зовсім іншого сенсового ряду). Поняття «компетентність» містить не тільки когнітивний та операційний - технологічний - складники, а й мотиваційний, етичний, соціальний, поведінковий [2, с. 38-39]. І. Зимня уперше теоретично обгрунтувала концептуальні засади угрупування ключових компетенцій, розмежувавши три основні групи компетенцій й окресливши змістове наповнення кожної: 
«Перша група. Компетенції, що стосуються самої людини як особистості, суб'єкта діяльності, спілкування. Це: компетенції здоров'язбереження (...); компетенції ціннісносенсової орієнтації в світі: цінності буття, життя, цінності культури (живопис, література, мистецтво, музика); науки; виробництва; історії цивілізацій, власної країни, релігії; компетенції інтеграції: структурування знань, ситуативно-адекватної актуалізації знань, розширення приросту накопичених знань; компетенції громадянськості: знання й дотримання прав і обов'язків громадянина, свобода й відповідальність, упевненість у собі, відчуття власної гідності, громадянський обов'язок, знання й гордість за свою державу; компетенції самовдосконалення, саморегулювання, саморозвитку, особистої та предметної рефлексії; сенс життя, професійний розвиток, мовний і мовленнєвий розвиток, оволодіння культурою рідної мови, володіння іноземними мовами.

Друга група. Компетенції, що стосуються соціальної взаємодії людини й соціальної сфери: компетенції соціальної взаємодії: із суспільством, спільнотою, колективом, сім'єю, друзями, партнерами, компетенції в конфліктах та їх розв’язанні, співпраця, толерантність, повага та прийняття іншого (раса, національність, релігія, статус, стать), соціальна мобільність; компетенції в спілкуванні: усному, письмовому, діалог, монолог, творення та прийняття тексту; крос-культурне спілкування; ділове листування; іншомовне спілкування, комунікативні завдання, рівень впливу на реципієнта.

Третя група. Компетенції, що стосуються діяльності людини: компетенція пізнавальної діяльності: постановка й розв'язання пізнавальних задач; нестандартні розв'язки, проблемні ситуації - їх створення та розв'язання; продуктивне й репродуктивне пізнання, інтелектуальна діяльність; компетенції діяльності: гра, навчання, праця, засоби та способи діяльності: планування, проектування, моделювання, прогнозування, дослідницька діяльність, орієнтація в різних видах діяльності; компетенції інформаційних технологій: прийом, перероблення й видача інформації; перетворення інформації (читання, конспектування), масмедійні, мультимедійні технології, комп'ютерна грамотність; володіння електронною інтернеттехнологією» [2].

Компетенція (В. Болотов, А. Дахін, В. Краєвський, В. Сєріков, А. Хуторськой) містить сукупність взаємопов'язаних знань, умінь, навичок, способів діяльності, заздалегідь заданих щодо певного кола проблем, предметів, процесів і необхідних для якісної продуктивної діяльності. Під компетенцією розуміють певну відсторонену, заздалегідь задану вимогу до загальноосвітньої підготовки учня; володіння людиною відповідною компетенцією, що містить ії особисте ставлення й до компетенції, і до предмета діяльності.

На думку А. Хуторського, у період шкільного навчання учень повинен оволодіти загальноосвітньою компетенцією, - сукупністю сенсових орієнтацій, знань, умінь, навичок та досвіду діяльності учня щодо певного кола об'єктів реальної дійсності, необхідних для здійснення особистісно та соціально значущої продуктивної діяльності. Перелік ключових компетенцій визначається на основі цілей загальної освіти, іiі змісту, структурного подання соціального досвіду й індивідуального досвіду особистості, а також основних видів діяльності учня, які дозволяють йому опановувати соціальний досвід, отримувати навички життя та діяльності в сучасному суспільстві. До таких ключових загальноосвітніх компетенцій російський дидакт відносить: ціннісно-сенсові, загальнокультурні (коло питань, щодо яких учень повинен бути добре обізнаним, мати знання та досвід діяльності: це й культурні особливості, духовно-моральні основи, культурологічні основи родинних, соціальних, суспільних взаємин і традицій, вплив науки й релігії на побутову та культурно-досугову сфери, досвід опанування учнем наукової картини світу); навчально-пізнавальні, інформаційні, комунікативні, соціальнотрудові, компетенція особистісного самовдосконалення. 
Цілком слушним видається зауваження О. Пометун про те, що тлумачення російськими дидактами терміна «компетенції» за значенням близьке до поняття «ключові компетентності» як його застосовують європейські науковці та міжнародні експерти: поняття ключових компетентностей (key competencies) (OECР) застосовується для визначення компетентностей, що дають змогу особистості ефективно брати участь у багатьох соціальних сферах і які роблять внесок у розвиток якості суспільства та особистого успіху, що може бути застосовано до багатьох життєвих сфер. Ключові компетентності становлять основний набір найзагальніших понять, які мають бути деталізовані в комплексі знань, умінь, навичок, цінностей та відносин за навчальними галузями та життєвими сферами школярів [5, с. 22]. «Вони (російські науковці) вважають, - зауважує О. Пометун, - що поняття ключових освітніх компетенцій належить до верхнього, загальнопредметного змісту освітніх стандартів, у ключових компетенціях концентровано та взаємозалежно втілено всі компоненти загальнопредметного змісту освіти: реальні об'єкти досліджуваної дійсності; загальнокультурні знання про досліджувану дійсність; загальні й загальнонавчальні вміння, навички, узагальнені способи діяльності. На їхню думку, ключові освітні компетенції конкретизуються на рівні навчальних предметів (освітніх галузей)» [3, c. 19-20]. Загалом, спільною особливістю російських досліджень у царині компетентнісного підходу $\epsilon$ те, що його науково-педагогічна методологія $є$ істотною об'єктоцентричною, тобто у більшості використовуваних концепцій основою є об' єкти й знання про них, тому докорінна його сутність визначається як спосіб діяльності щодо певних об'єктів. Зіставлення російських і західноєвропейських досліджень у галузі компетентнісного підходу свідчить, що у перших компетенції та компетентності розглядаються в основному як своєрідні ідеальні сутності, що потребують пояснення й осмислення, а інші (західноєвропейські та американські дослідники) ці категорії тлумачать як посткласичний (некласичний) феномен, що вже укорінився в суспільній освітній практиці й відбиває баланс інтересів суспільства, освітніх інститутів, роботодавців, споживачів послуг.

Натомість, більш повною й виправданою нам видається інша позиція: дефініція «компетенція» передбачає дихотомічність розуміння поняття, зазначає вітчизняна дослідниця О. Усик, що розглядається, з одного боку, як правомірність суб'єкта, а 3 іншого, - як його обізнаність із конкретних питань; відображає як кількість, так і якість знань і вмінь людини у певній сфері діяльності. Компетенція $є$ важливою також у вимірах здатності індивіда не тільки добре орієнтуватися в навколишньому світі, ефективно, автономно й творчо щось робити, але й адекватно реагувати на різні нестандартні ситуації, що можуть постати у процесі діяльності [6, с. 21-22].

Класики дидактики (В. Краєвський, І. Лернер, М. Скаткін), досліджуючи проблему формування навчальних умінь учнів у процесі навчально-пізнавальної діяльності, створили фундамент досліджень різноманітних компетентностей. Беззаперечно важливими є знання, уміння та навички, котрі молодь набуває й виробляє у процесі навчання у школі. Поряд із цим актуальності набуває поняття компетентностей, що пов'язано з багатьма чинниками, оскільки саме компетентності є тими індикаторами, які дозволяють визначити готовність учня, випускника до життя, його подальшого розвитку й активної участі в житті суспільства [5, с. 16]. Ця думка є стрижневою для вітчизняних наукових і науково-методичних досліджень означеного напрямку.

У більшості своїх публікацій із цієї проблеми і вітчизняні, i зарубіжні науковці вказують на іii складність загалом та складність розмежування «компетенцій/ компетентностей» зокрема: «... розгляд компетенції/компетентності у загальному плані 
становлення компетентнісного підходу до освіти свідчить... про дуже велику складність їх вимірювання й оцінювання» $[1$, с. 41$]$.

Тривалі дискусії навколо понять «компетенція/компетентність» дозволили виокремити чотири базові характеристики поняття «компетентність». О. Пометун доходить висновку про те, що: для демонстрації компетентності обов'язково потрібен контекст; компетентність завжди є результатом, вона є характеристикою того, що може робити індивід, а не описує процес, під час якого індивід набув цю компетентність; для вимірювання здатності індивіда щось робити потрібні чітко визначені та затверджені стандарти; компетентність $є$ мірою того, що індивід може робити в конкретно визначений час [4].

Думки вітчизняних (Н. Бібік, О. Овчарук, О. Пометун) науковців збігаються в тому, що до ознак ключових компетентностей варто віднести поліфункціональність, надпредметність, міждисциплінарність, багатокомпонентність, спрямування на формування критичного мислення рефлексії, визначення власної позиції, ключові компетентності дозволяють розглядати в тісному взаємозв'язку особистісне й соціальне в освіті, відбивають комплексне оволодіння сукупністю способів діяльностей, що створює передумови для розроблення індикаторів їх вимірювання; вони виявляються не взагалі, а в конкретній справі чи ситуації; їх набуває молода людина не лише під час вивчення предметів, групи предметів, але й засобами неформальної освіти, унаслідок впливу середовища тощо.

«Компетентнісно-орієнтований підхід до формування змісту освіти став новим концептуальним орієнтиром шкіл ... Саме набуття життєво важливих компетентностей, вважається у багатьох розвинених освітніх системах, може дати можливості дитині орієнтуватись у сучасному суспільстві, інформаційному просторі, швидкоплинному розвиткові ринку праці, подальшому здобутті освіти», - пише О. Овчарук на сторінках колективного наукового доробку «Стратегія реформування освіти в Україні: Рекомендації з освітньої політики». Тож в українських реаліях компетентнісний підхід нині відіграє роль, по-перше, провідної науково-методологічної парадигми, по-друге, він $є$ відповіддю на потребу привести у відповідність масову загальноосвітню школу та ринок праці. Дослідники дійшли висновку, що ідея компетентнісного підходу - це ідея відкритого замовлення на зміст освіти.

Національні європейські системи освіти протягом двох останніх десятиліть поступово перейшли на нові засади середньої освіти, основними рисами якої $є$ : домінування інтегрованих завдань освіти над предметними; затвердження діяльнісного підходу на противагу елементарному накопиченню вмінь і навичок; перехід на нову систему оцінки якості освіти; партнерство та співпраця педагога й учнів у навчальній діяльності.

Отже, нині саме компетентнісний підхід $є$ провідним у визначенні нових стандартів загальноосвітньої підготовки учнів. Наочне організаційне втілення цього підходу маємо у профільній моделі організації старшої ланки навчання: організації старшої школи за одним профілем (наприклад, гуманітарним, математичним, технічним тощо,- гуманітарні гімназії, природничо-науковий ліцей тощо) або за багатьма профілями (за наявності необхідних педагогічних кадрів, ресурсів тощо). Окрім того, організовується профільне навчання на базі опорних шкіл, що мають більше ресурсів і необхідні педагогічні й науково-педагогічні кадри, використовуються ресурси різних шкіл для профільного навчання в мережі декількох шкіл. Компетентнісний підхід $\epsilon$ провідним у широкому застосуванні дистанційних форм навчання, кооперації декількох навчальних закладів різних типів і рівнів (наприклад, залучення необхідних фахівців 3 
вищих навчальних закладів, училищ для викладання в ліцеях, гімназіях та старшій ланці загальноосвітніх шкіл), ступенях поглибленого навчання з різних предметів.

Специфіка компетентнісного навчання у старшій школі полягає не лише в тому, що засвоюється «готове знання», запропоноване вчителем для сприйняття, а й простежуються умови виникнення цього знання, передбачається, що учень сам формулює поняття, необхідні для розв'язання завдань. Навчальна діяльність, перетворюючись на дослідницьку, сама стає предметом засвоєння. Саме компетентнісний підхід спонукає старшокласника до навчання. I педагог, і учень починають розуміти, що справжня революція в навчанні полягає не лише у змісті шкільної системи. Вона полягає в навчанні того, як навчатися, думати, які методи можна використати задля розв'язання будь-якого завдання, що виникає перед особистістю у будь-якому віці.

\section{Література}

1. Зимняя И. А. Ключевые компетентности как результативно-целевая основа компетентносново подхода в образовании. Авторская версия / Ирина Алексеевна Зимняя. - М. : Исследовательский центр проблем качества подготовки специалистов, 2004. - 42 с. 2. Зимняя И. А. Ключевые компетенции - новая парадигма результата образования / И. А. Зимняя // Высшее образование сегодня. - 2003. - № 5. - С. $34-42$. 3. Компетентнісний підхід у сучасній освіті : світовий досвід та українські перспективи: бібліотека з освітньої політики : [монографія] / Н. М. Бібік, Л. С. Ващенко, О. І. Локшина та ін.; [під заг ред. О. В. Овчарук]. - К. : К. І. С., 2004. - 112 с. 4. Пометун О. І. Компетентнісний підхід - найважливіший орієнтир розвитку сучасної освіти / О. І. Пометун // Рідна школа. - 2005. - №1. - С. 65-69. 5. Стратегія реформування освіти в Україні: Рекомендації з освітньої політики / [за заг. ред. В. Кременя]. - К. : К. І. С., 2003. - 296 с. 6. Усик О. Ф. Формування соціокультурної компетентності студентів філологічних спеціальностей у процесі вивчення гуманітарних дисциплін / Олена Федорівна Усик: дис. ... канд. пед. наук: 13.00.09. - К. Інститут педагогіки АПН України, 2010. - 275 с. 7. Hoffman T. The meanings of competency / T. Hoffman // Journal of European Industrial Training, 1999. - Vol. 23. - № 6. - P. 277.

\section{ОСОБЛИВОСТІ ВИКОРИСТАННЯ ПРОЕКТНОЇ ТЕХНОЛОГІЇ НА УРОКАХ АНГЛІЙСЬКОЇ МОВИ В ПОЧАТКОВИХ КЛАСАХ}

Пінчук I .О. Особливості використання проектної технології на уроках англійської мови у початкових класах.

У статті схарактеризовано сутність і процедуру використання проектів у процесі навчання англійської мови учнів початкової школи, розглянуто вимоги та завдання проектної технології в початковій школі. Описано особливості основних етапів роботи і підкреслено значення проектної технології.

Ключові слова: проектна технологія, учень початкової школи, освітній процес 3 англійської мови в початковій школі, презентація проекту.

Пинчук И. А. Особенности использования проектной технологии на уроках английского языка в начальных классах.

В статье охарактеризованы суть и процедура использования проектов в процессе обучения английскому языку учащихся начальной школы, рассмотрены требования и 